\title{
HUBUNGAN HIPOALBUMIN DENGAN KEJADIAN TUBERCULOSIS LULUH PARU DI PROVINSI LAMPUNG TAHUN 2017
}

\author{
Hetti Rusmini ${ }^{1}$, Rakhmi Rafie ${ }^{2}$, Retno Ariza ${ }^{3}$, Fahmi Fathul Rahman ${ }^{4}$ \\ 1Departemen Farmakologi Fakultas Kedokteran Universitas Malahayati \\ 2Departemen Anatomi Fakultas Kedokteran Universitas Malahayatis \\ 3Departemen Pulmonologi Fakultas Kedokteran Universitas Lampung \\ 4Program Studi Kedokteran Fakultas Kedokteran Universitas Malahayati
}

\begin{abstract}
The Relationship Hypoalbumin with Tuberculosis Destroyed Lung in Province of Lampung, 2017. Tuberculosis (TB) is one public health problem in the world as well as in Indonesia. Indonesia occupies the position of the two countries by the number of tuberculosis cases in the world after India with a mortality rate of about 100,000 cases in 2015 . The high number of TB deaths are progressive and inadequate treatment, which can cause complications such as TB-destroyed lung. Worsening conditions in TB patients is one of them caused by poor nutritional status (malnutrition), which can be assessed by serum albumin. This study aims to determine the relationship hypoalbumin with TBdestroyed lung. Observational analytic research with the approach of case control studies. The subjects of this study were 60 people, divided into two groups: 30 groups of cases (TB-destroyed lung) and 30 control group (pulmonary TB). Measurement of albumin from the month from February to March 2017. The statistical test Chi-square test Correlation. The frequency distribution of TBdestroyed lung based on the age at most in the age range 18-55 years is 17 people $(56.7 \%)$, by sex more male patients with 21 patients $(70 \%)$, and by category albumin, hypoalbumin obtained by 20 patients $(66.7 \%)$. Based on the obtained correlation test $p$ value $=0.002(O R=5.50 r=0.372)$. There was a significant relationship between hypoalbumin with TB-destroyed lung in Lampung Province 2017.
\end{abstract}

Keywords: Hypoalbuminemia, TB-destroyed lung.

Abstrak: Hubungan Hipoalbumin dengan Kejadian Tuberculosis Luluh Paru di Provinsi Lampung Tahun 2017. Tuberkulosis (TB) merupakan salah satu masalah kesehatan di republic Indonesia. Indonesia menempati urutan kedua setelah India untutk kasus TB dengan kematian 100,000 kaus di tahun 2015. Penyebab tersering kematian Tb adalah perkembangan dan pengobatan TB yang tidak adekuat sehingga menyebabkan komplikasi seperti TB luluh paru. Perburukan kondisi pasien TB disebabkan oleh buruknya status nutrisi (malnutrisi) yang dapat dinilai melalui kadar serum albumin. Tujuan penelitian ini adalah untuk mengetahui hubungan antara hipoalbuminemia dengan kejadian TB luluh paru. Desain penelitian adalah analitik observasi dengan pendekatan case control. Diman subjek peneltian berjumlah 60 orang yang dibagi menjadi 30 orang kelompok kontrol (TB Paru) dan 30 orang lainnya kelompok kasus (TB luluh Paru). Pengukuran kadar albumin dilakukan pada bulan Februari hingga Maret 2017. Analisa statistik menggunakan uji chi square. Distribusi frekuensi TB luluh paru berdasarkan usia didapatkan usia $18-55$ tahun sebanyak 17 orang $(56,7 \%)$, berdasarkan jenis kelamin didapatkan lebih banyak pasien laki-laki sebanyak 21 orang $(70 \%)$, berdasarkan kadar albumin didapatkan sebanyak 20 orang mengalami hipoalbumnemia $(66,7 \%)$. Hasil uji korelasi menunjukkan nilai $\mathrm{p}=$ $0,002(\mathrm{OR}=5,5 \mathrm{r}=0,372$ ). Terdapat hubungan bermakna antara Hipoalbuminemia dengan Kejadia TB Luluh Paru. 
Kata kunci: Hipoalbuminemia, Tuberkulosis, TB Luluh Paru.

\section{PENDAHULUAN}

Tuberkulosis (TB) adalah suatu penyakit menular yang disebabkan oleh spesies Mycobacterium. Mycobacterium tuberculosis, sejenis kuman berbentuk batang. Sebagian besar dinding kuman terdiri atas asam lemak (lipid), peptidoglikan dan arabinomanan yang menyebabkan kuman ini lebih tahan terhadap asam sehingga disebut bakteri tahan asam (BTA). Selain menyerang paru, Mycobacterium tuberculosis ini juga dapat menyerang bagian lain dari tubuh seperti kelenjar getah bening, ginjal, tulang, sistem saraf pusat, peritoneum, mata serta kulit dan menyebar melalui udara saat orang yang memiliki penyakit ini bersin atau meludah (Shingdang, 2016).

Tuberkulosis (TB) sampai saat ini masih merupakan salah satu masalah kesehatan masyarakat di dunia walaupun upaya pengendalian dengan strategi Directly Observed Treatment Short Course (DOTS) telah diterapkan dibanyak negara sejak tahun 1995 (Kemenkes RI, 2014). Dalam Laporan WHO tahun 2013, diperkirakan terdapat 8,6 juta kasus TB, pada tahun 2012 dimana 1,1 juta orang (13\%) diantaranya adalah pasien TB dengan HIV positif. Sekitar $75 \%$ dari pasien tersebut berada di wilayah Afrika. Selain itu, diperkirakan terdapat 450.000 orang menderita Multi Drug Resistant Tuberculosis (MDR-TB) dan 170.000 orang diantaranya meninggal dunia (Kemenkes RI, 2014). Prevalensi TB di Indonesia cukup tinggi. Indonesia menempati posisi dua besar negara dengan jumlah kasus tuberkulosis terbanyak di dunia setelah India. Pada tahun 2015 ditemukan jumlah kasus BTA+ sebanyak 1000.000 kasus, dengan angka kematian sekitar 100.000 kasus (Kurniawan, 2016).

Di Provinsi Lampung, perkiraan kasus TB BTA $(+)$ mengacu pada insidens rate Lampung sebesar 160 per 100.000 penduduk, perkiraan insiden semua kasus TB tahun 2014 yaitu case notification rate semua kasus sebesar 224 per 100.000 penduduk. Angka notification semua kasus TB sebesar 94 per100.000 penduduk (Dinkes Prov. Lampung, 2014).

Faktor-faktor yang menyebabkan tingginya angka kematian pada pasien TB paru adalah TB yang progresif dan pengobatan yang tidak adekuat, sehingga menyebabkan komplikasi berupa tuberkulosis (TB) luluh paru (Eren, 2003). Luluh paru (destroyed lung) merupakan penyebab kematian yang sering ditemukan pada pasien $T B$, sebanyak $83,3 \%$ kasus TB menjadi penyebab luluh paru. Luluh paru merupakan komplikasi pada TB dengan gambaran radiologi yang menunjukkan kerusakan jaringan paru berat yang terdiri dari atelektasis, ektasis/ multikaviti dan fibrosis parenkim paru. TB luluh paru dihasilkan dari TB progresif selama bertahun-tahun dan pengobatan yang tidak adekuat, dan biasanya mengarah pada obstruksi bronkus dengan kombinasi kolaps distal, nekrosis dan infeksi sekunder/koinfeksi (PDPI, 2006).

Pasien dengan TB luluh paru memiliki manifestasi klinis serupa dengan penyakit paru obstruktif kronik (PPOK) tetapi berbeda patofisiologinya. Manifestasi klinis dari TB luluh paru ini adalah dispnea progresif, hemoptisis dan penurunan berat badan. Penyebab kematian pada TB luluh paru adalah hemoptisis massif dan gagal napas (Ryu, 2011).

Obstruksi pernapasan pada pasien TB luluh paru merupakan manifestasi dari rusaknya beberapa fitur anatomi paru, misalnya keruksakan bronkus akibat fibrosis yang luas atau striktur endobronkial (Lee, 2013). Selain itu, adanya proses fibrosis pada 
pasien TB luluh paru juga mengakibatkan pengurangan volume paru (Lee, 2003).

Perburukan kondisi pada pasien TB ini salah satunya diakibatkan oleh status gizi yang buruk (malnutrisi). Malnutrisi adalah keadaan yang sering ditemukan pada pasien TB. Malnutrisi akan meningkatkan risiko penyakit tuberkulosis paru. Sebaliknya, Infeksi TB mengakibatkan penurunan asupan dan malabsorpsi nutrien serta perubahan metabolisme tubuh sehingga terjadi proses penurunan massa otot dan lemak (wasting) sebagai manifestasi malnutrisi energi protein (Puspita, 2016).

Salah satu indikator yang dapat digunakan untuk melihat keadaan malnutrisi adalah serum albumin. Albumin merupakan protein utama dalam plasma manusia dan membentuk sekitar $60 \%$ protein plasma total. Sekitar $40 \%$ albumin terdapat dalam plasma dan $60 \%$ sisanya terdapat di ruang ekstrasel. Kadar serum albumin rendah merupakan prediktor penting dari mordibitas dan mortalitas (Putri, 2016).

Kadar albumin yang rendah juga berkontribusi pada komplikasikomplikasi yang terkait pada pasien TB paru karena albumin merupakan komponen penting plasma darah dengan aktifitas antioksidannya terutama untuk mengikat asam lemak bebas. Pro- oksidan (radikal bebas) dapat menyerang membran sel yang mengakibatkan kerusakan jaringan pada pasien TB (Akiibinu, 2007). Selain itu, kadar albumin yang rendah juga menunjukan prognosis yang buruk pada pengobatan pasien TB (Puspitasari, 2013).

Sebelumnya penelitian mengenai pengukuran kadar albumin pada pasien TB luluh paru pernah dilakukan oleh Park dkk di Korea pada tahun 2001 pada 38 pasien dengan kasus tuberkulosis luluh paru. Penelitian ini menunjukan bahwa pada pasien TB luluh paru terdapat penurunan kadar albumin (hipoalbumin) dengan nilai rata-rata $3.0 \pm 0.6 \mathrm{~g} / \mathrm{dl}$. Namun, penelitian ini tidak membahas adanya hubungan antara hipoalbumin dengan TB luluh paru.

Berdasarkan latar belakang diatas, peneliti merasa tertarik untuk mengetahui hubungan antara hipoalbumin dengan TB luluh paru di Provinsi Lampung tahun 2017, untuk mempelajari kemungkinan pemberian suplemen nutrisi untuk meningkatkan sistem imun pasien TB sehingga mencegah terjadinya komplikasi kearah luluh paru.

\section{METODE}

Penelitian ini merupakan jenis penelitian yang bersifat analitik observasional dengan pendekatan case control. Penelitian ini dilakukan di Provinsi Lampung yang meliputi tiga tempat, yaitu RSUD Dr. H. Abdul Moeloek Provinsi Lampung, RSUD Dr. A. Dadi Tjokrodipo Kota Bandar Lampung dan Klinik Harum Melati Pringsewu pada bulan Februari Maret 2017. Teknik sampling yang digunakan pada penelitian ini adalah total sampling. Data pada penelitian ini adalah data primer. Data univariat dianalisa secara deskriptif.

\section{HASIL DAN PEMBAHASAN}

Adapun usia penderita TB luluh paru dan tb paru di Provinsi Lampung Tahun 2017. Dapat dilihat pada tabel berikut ini:

\section{Tabel 1. Karakteristik TB Luluh Paru dan TB Paru Berdasarkan Usia di Provinsi Lampung Tahun 2017}

\begin{tabular}{ccccc}
\hline \multirow{2}{*}{ Usia } & \multicolumn{2}{c}{ TB Luluh Paru } & \multicolumn{2}{c}{ TB Paru } \\
\cline { 2 - 5 } & $\mathrm{N}$ & $\%$ & $\mathrm{~N}$ & $\%$ \\
\hline$\leq 17$ tahun & 0 & 0 & 2 & 6,7 \\
$18-55$ & 17 & 56,7 & 17 & 56,7 \\
tahun & & 43,3 & 11 & 36,7 \\
$\geq 56$ tahun & 13 & 100 & 30 & 100 \\
\hline Jumlah & 30 & 100
\end{tabular}

Tabel 1 memperlihatkan bahwa karakteristik pasien TB luluh paru berdasarkan usia paling banyak pada 
rentang usia 18-55 tahun yaitu 17 pasien dengan persentase $56,7 \%$. kemudian pasien TB luluh paru usia $\geq$ 56 tahun sebanyak 13 orang dengan persentase $43,3 \%$. Sedangkan pada pasien TB paru berdasarkan usia paling banyak pada rentang usia 1855 tahun yaitu 17 orang dengan persentase $56,7 \%$, kemudian pasien TB paru usia $\geq 56$ tahun sebanyak 11 orang dengan persentase $36,7 \%$, dan pasien TB paru usia $\leq 17$ tahun sebanyak 2 orang dengan persentase $6,7 \%$.

Tabel 2. Karakteristik Pasien TB Luluh Paru dan TB Paru Berdasarkan Jenis Kelamin di Provinsi Lampung Tahun 2017

\begin{tabular}{ccccc}
\hline Jenis & \multicolumn{2}{c}{ TB Luluh Paru } & \multicolumn{2}{c}{ TB Paru } \\
\cline { 2 - 5 } Kelamin & $\mathrm{N}$ & $\%$ & $\mathrm{~N}$ & $\%$ \\
\hline Laki-laki & 21 & 70 & 19 & 63,3 \\
Perempuan & 9 & 30 & 11 & 36,7 \\
\hline Jumlah & 30 & 100 & 30 & 100 \\
\hline
\end{tabular}

Tabel 2 memperlihatkan bahwa karakteristik pasien TB luluh paru berdasarkan jenis kelamin, lebih banyak pasien laki-laki sebanyak 21 orang dengan persentase $70 \%$. Pasien perempuan pada TB luluh paru sebanyak 9 orang dengan persentase $30 \%$. Sedangkan pada pasien TB paru dengan jenis kelamin laki-laki sebanyak 19 orang dengan persentase $63,3 \%$ dan jenis kelamin perempuan sebanyak 11 pasien dengan persentase $36,7 \%$.

Tabel 3. Karakteristik Pasien TB Luluh Paru dan TB Paru Berdasarkan Kategori Hipoalbumin di Provinsi Lampung Tahun 2017

\begin{tabular}{ccccc}
\hline \multirow{2}{*}{ Hipoalbumin } & \multicolumn{2}{c}{ TB Luluh Paru } & \multicolumn{2}{c}{ TB Paru } \\
\cline { 2 - 5 } & $\mathrm{N}$ & $\%$ & $\mathrm{~N}$ & $\%$ \\
\hline Ya & 20 & 66,7 & 8 & 26,7 \\
Tidak & 10 & 33,3 & 22 & 73,3 \\
\hline Jumlah & 30 & 100 & 30 & 100 \\
\hline
\end{tabular}

berdasarkan kategori hipoalbumin, lebih banyak pasien hipoalbumin sebanyak 20 orang dengan persentase $66,7 \%$. Pasien dengan kadar albumin normal pada TB luluh paru sebanyak 10 orang dengan persentase 33,3\%. Sedangkan pada pasien TB paru pasien dengan hipoalbumin sebanyak 8 orang dengan persentase $26,7 \%$. Pasien dengan kadar albumin normal pada TB paru sebanyak 22 orang dengan persentase $73,3 \%$.

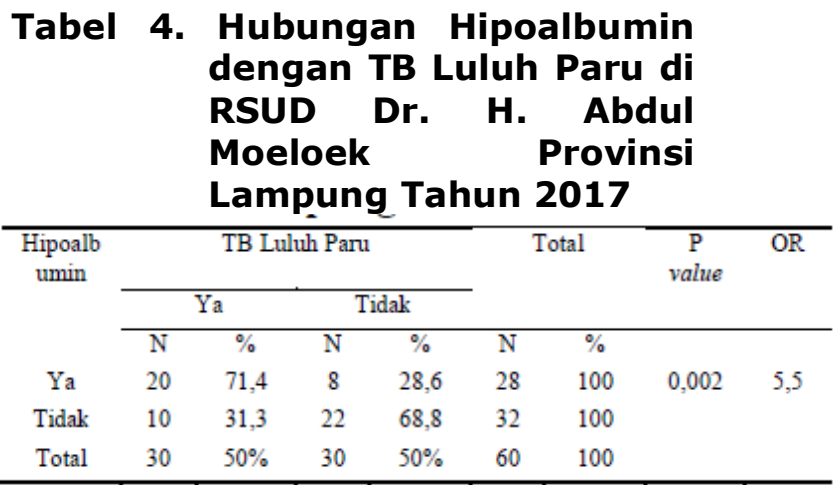

Tabel 4 memperlihatkan bahwa berdasarkan uji statistik Chi-square diperoleh nilai $\mathrm{p}$ value $=0,002(\mathrm{OR}=$ $5,50 \mathrm{r}=0,372)$, maka dapat disimpulkan bahwa ada hubungan bermakna antara hipoalbumin dengan TB luluh paru. Dari nilai OR (Odds Ratio) dapat dikatakan bahwa pasien TB paru dengan hipoalbumin 5,5 kali lebih besar resiko mengalami TB luluh paru. Dari nilai $r$ (koefisien korelasi) menunjukan korelasi positif dengan kekuatan korelasi yang lemah.

\section{KESIMPULAN}

A. Distribusi frekuensi TB luluh paru di Provinsi Lampung tahun 2017 berjumlah 30 orang.

B. Distribusi frekuensi hipoalbumin pada pasien TB luluh paru lebih banyak pasien yang hipoalbumin yaitu sebanyak 20 orang dengan persentase $71,4 \%$.

C. Ada hubungan bermakna antara hipoalbumin dengan TB luluh paru di Provinsi Lampung tahun 2017.

Tabel 3 memperlihatkan bahwa karakteristik pasien TB luluh paru 
DAFTAR PUSTAKA

Akiibinu, M.O., Arinola, O.G., Ogunwele, J.O., Onih, E.A. (2007). Non Enzimatic Antioksidants And Nutritional Profiles in Newly Diagnosed Pulmonary Tuberculosis Patients In Nigeria. African Journal of Biomedical Research, vol. 10, 223-228.

Dinkes Provinsi Lampung. (2015). Profil Kesehatan Provinsi Lampung Tahun 2014. Bandar Lampung. Dinas Kesehatan Pemerintah Provinsi Lampung.

Kementrian Kesehatan Republik Indonesia Direktorat Jendral Pengendalian Penyakit dan Penyehatan Lingkungan. (2014). Pedoman Nasional Pengendalian Tuberkulosis. Jakarta: Kementrian Kesehatan RI.

Kurniawan A H., Mertaniasih N. M., Soedarsono. 2016. Susceptibility of RifamficinIsoniazid Resistant Mycobactrerium TuberculosisIsolate

Lee, J. H., Chang, J. H. (2003). Lung Function in Patients with Chronic Airflow Obstruction Due to Tuberculous Destroyed Lung. Respiratory Medicine; 97, 1237-1242.

Lee, S. D., Kim, J. H., Oh, Y. M., Rhee, C. K., et al. 2013. Clinical Characteristics of Patients With Tuberculosis Destroyed Lung. Int J Tuberc Lung 2013, Dis 17(1), 67-75.

Perhimpunan Dokter Paru Indonesia. (2006). Pedoman Diagnosis dan Penatalaksanaan di Indonesia.

Puspita, E., Christianto, E., Yovi, I. 2016. Gambaran Status Gizi Pada Pasien TB Paru Yang Menjalani Rawat Jalan Di RSUD Achmad Pekanbaru. JOM FK, vol. 3 no. 2.

Puspitasari P. Profil Pasien Tuberkulosis Paru di Poliklinik Paru RSUP Prof. Dr. $R$.
D.Kandau Manado. [Skripsi]. Manado: FK Unsrat.

Putri, T. D., Mongan, A. E., Memah, M. F., (2016). Gambaran Kadar Albumin Serum Pada Pasien Penyakit Ginjal Kronik Stadium 5 Non Dialisis. Jurnal E biomedik, vol. 4. no. 1, 173177.

Ryu, J. J., Lee, J. H., Chun, E-M., Chang, J. H., Shim, S. S. (2011). Clinical Outcomes and Prognostic Factors in Patients With Tuberculous Destroyed Lung. Int J Tuberc Lung 2011, Dis 15(2), 246-250.

Shingdang, J., Bot, Y,. Ojo, O,. et al. (2016). Serum Albumin/Globulin Ratio in Tuberculosis and HIV Patients Any Relationship?. Mycobac Dis. Vol. 6. 